\title{
Bell 麻痺の手術適応に関する私見
}

神崎仁

私のベル麻瘏に対する手術療法の考えは 6 年 前に述べた条件付賛成 ${ }^{1)}$ と基本的には変ってい ない。

実際には, 手術による有効例が存在すると思 われるが，適確にそのような症例を選択するこ とが困難なため研究者によりその基準が異なっ ているにすぎないと考えている，現在の電気診 断法は脱神経と診断しても, どの程度の神経線 維が残存しているかまでは診断できない。した がって少し幅をみて，てれは危いと推定した例 までも手術をすることになる。私には May の 適匛は ${ }^{8}$ Electroneuronography（以下 ENoG と略）ひとつとっても $25 \%$ 以下を手術の檤応之 している点からも，甘い基準の印象を受ける。 また充分追跡された症例が少ない（7例）.

保存的あるいは外科的治療の有効性が証明さ れるためには, ベル麻脾の場合, 自然治癒の成 績を上回らねばならない。

発例後 3 日以内にプレドニソンを投与すれ ば脱神経はみられない2 との報告ああるが，患 者は必ずし屯 3 日以内に米院しない，また同様 に3 日以内にクロモリンナトリウム（インター ル）の吸入を頻回に行うと $100 \%$ 治癒が得られ るとの報告むある3 .

15年間に1011例のベル麻㫌の自然経過を観察 した報告 ${ }^{4)}$ によると高令者ほよ゙完全治癒が少 く, また最終判定で高度㑣痺と判定されたもの は $4 \%$ にすぎず等度麻痺は $12 \%$ あっあた この統計からは手術的療法が挑戦できる相手 は $4 \%$ 程度であることを示唆していると思われ る.

May らの予後判定では37\%（60例）が手術
の対象とされ42例に対して施行されている．年 間の平均例数として 7 例である. 小池ら ${ }^{6)}$ の報 告でも $\mathrm{ENoG}$ にて $5 \%$ 以下のものは 165 例中 19例（11\%）であり年間平均 3 例にすぎない.

$\mathrm{Fisch}^{7}$ は 4 年間に適応例は27例あり，そのう ち14例に迷路部を中心とする減荷手術を行って いる(年間平均 3.5 例).乙のように適応例はべ ル麻痖を精力的に行っている施設でも年間10例 に満たない。

電気診断法で無反応の時点で手術を行った場 合，例外はあるが予後不良である ${ }^{8)}$ とすれば， ますます適応例は限られてくる，むし無反応の 症例屯発症後早期例に限って手術をしたとすれ ば Fisch，May らと結果が違ってくるであろ う. 個人的経験でも来院時に電気的診断法で無 反応であった例では（手術時期は種々であった が）完全治癒はみられなかった。

このようにベル麻瘏では手術の適応のみなら ず手術時期, 手術範囲についても種々の見解が だされてきた。しかし私見では Fisch の報告以 来, 手術を行うとすれば迷路部を減荷しなけれ ば意味がないように考えている．1984年 9 月に ボルドーで行われた第 5 回国際顔面神経シンポ ジウムで， ロンドンの O’Donoghue らはベル 麻舫で迷路部に限局した変性を示した側頭骨病 理所見を報告し注目された。ベル穈瘦の原因は 不明であるが，原因のいかんに拘らず迷路部の 限局性病変であるとするならば, ベル林痺のみ ならずハント症候群も手術の対象となり，アプ ローチとして中頭蓋窩経由法加経乳突的手術 ${ }^{8}$ のいずれかが行われる必要がある.

一う，顔面痤攣と同様な機転でベル晽猈が発 
症するとの仮説むみられるが, 迷路部に涡変の みられなかった例が存在するのかについての乨 載はみられないようである.

したがってベル麻舥について手術の適匛例を Fisch の法で選択するためには, 発症早期例 については発症後最低 2 週間は連日電気晾断と 随時その他の予後判定に必要な検査を行って脱 神経の徵候を無反応になる前に予知しなければ ならない。すしての徽候が確認できたら緊急手 術を行わねばならないが, 加刀直前に電気的に 無反応であったらどうするかが問題であろう。 ベル麻痺の10\%以下の症例の選択のために全例 に速日に検査を行うことは非現実的であり，ま

1) 神崎 仁: Bell 麻焷における手術適応について の考察. 耳鼻臨床 $72: 711 \sim 713,1979$.

2) Adour KK, et al: Idiopathic facial paralysis (Bell's palsy): Factors affecting severity and outcome in 446 patients. Neurology $24: 1112$ 〜116, 1974.

3) McGovern $\mathrm{FH}$, et al: The use of cromolyn sodium in the prevention of nerve degeneration in Bell's palsy. Laryngoscope 90 : 1640 1645, 1980.

4) Peitersen E: The natural history of Bell's palsy. Amer J Otolgy $4: 107 \sim 111,1982$.
た緊急手術を 24 時間以内に行うことは必ずしむ 容易ではない。

もし May らのように予後判定の指愫を多く 用いると手術適応例は増える一方緊急度は少 くなるが，手術過多，亡なる可能性がある。乙 こまでくればあとは治療哲学の問題と考えられ るので, 恥力障嘒を起さずに, 勿論, 顔面神経 に損傷を与えることなく迷路部の手術を行える 熟練した神経耳科外科医に委悋てよいであろ う。ベル麻旿の手術適応例は決して頻度の多い ものでなく，したがって手術は限られた施設の 限られた術者に委称るべきものと考える。

献

5) May M, et al: Bell's palsy : Surgery based upon prognostic indications and results. Laryngoscope 91:2092 2105, 1981.

6 ）小池吉郎, 他：末梢性顔面神経麻焷に対する減荷 手術の適用の問題点. 耳食 $27: 15 \sim 23,1984$.

7) Fisch U: Surgery for Bell's palsy. Arch Otolaryngol 107: 1 11, 1981.

8) May M: Total facial nerve exploration: Trans-mastoid, extralabyrinthine, and subtemporal indications and results. Laryngoscope $89: 906 \sim 917,1979$.

\section{ベル麻痺例への対応一その問題点一}

細見英男

1) 新䰻例における休猈の経過の予测 ベル麻痖例は発症後一週をすぎる将点で森㽻 の予後を推測できる。二週を経た時点では自然 経過は䀩確定すると思われる。

いまここに新魚例予後につき大峈の数をあげ
る。症例山完全休痺例（顔面連動が垫められな い) と不完全麻痺例（運動を明らかに認め得る） はそれぞれ約 $50 \%$ ある。，発症後一週を経てな お不完全㾁㾝にとどまる例はすべて完全回復す る。䀩一週の経過で完全林痺に移行する症例を 